\title{
広島県農村における血液性状よりみた健康の 基礎的指標に関する研究
}

\author{
高 科 成 良 ${ }^{*}$
}

\section{緒}

\section{言}

従来，農民の健康状態を調査研究した報告は多数み らけられるが，大多数のものは既存の正常值を規準に して論じたもので，健康の指標設定に関するものは数 少ないようであり 1) 7), 特に血液性状よりみた健康の 指標を追求したものは少ない３４）。一方近年農民の健 康管理が注目されるよらになり，各地で実施されてき ている。この様な時期に農村における血液性状よりみ た健康の基礎的指標について研究することは重要なこ とであると考えられ，昭和 $52 ， 53 ， 54$ 年度にこの問題 を追求し，若干の知見を得たのでここに報告する。

\section{研 究 万 法}

研究を始めるにあたり，「健康」といら問題を考えて みる必要がある。WHO の保健憲章によると「健康と は, 単に虚弱や疾病がないといらだけでなく, 肉体的, 精神的ならびに社会的に完全に良好な状態」と定義さ れているが, やや漠然としているので, この研究の対 象とした健康者とは, 多少の自覚症はあっても日常活 動にことかかないものであり，何らかの疾患があり治 療を受けているものは除外した。

1 ）第 1 年度は, 農村居住の健康を自認しているも のを対象に，後述する様な医学的検査を行ない，その 実態を把握することにつとめた。

2）第 2 年度は, 第 1 年度とは異なった対象ではあ るが，昭和52年度と53年度に医学的検査を受けた同一 対象の身体状況, 特に血液性状の変動について調査し た。

3 ）第 3 年度は健康を自認している農業従事者につ いて血液性状, 摂取栄養量, 労働との関連について追 求した。

$$
\text { 成 績 }
$$

1. 第 1 年度研究

\footnotetext{
* 広島県厚生連 広島総合病院
}

(1) 対象は広島県内農業地帯 (中北部) に居住し, 健康を自認している30才代より60才にわたる男性 167 人，女性 187 人である。これら対象について肥満度，血 圧, 尿蛋白, 血色素, ヘマトクリット, 経口50 g ブドー 糖負荷試験, 総コレステロール, 中性脂肪, 尿酸, ア ルブミン, コリンエステラーゼを測定し, 現在使用し ている正常値を規準にしてみた場合の異常率の頻度と 各測定項目の平均値を算出し, 珄別, 年龄別に検討し

表 1, 判定基準および測定法

\begin{tabular}{|c|c|c|}
\hline 検査項目 & 規 準 值 & 測定方法 \\
\hline 血 色 素 & $\begin{array}{l}\text { 男性 } 12.0 \sim 18.0 \mathrm{~g} / \mathrm{dl} \\
\text { 女性 } 11.0 \sim 15.0 \mathrm{~g} / \mathrm{dl}\end{array}$ & \multirow{2}{*}{$\begin{array}{c}\text { コールターカウンター } \\
\mathrm{S} \text { 型 }\end{array}$} \\
\hline ヘマトクリット & $\begin{array}{l}\text { 男性 } 35.0 \sim 50.0 \% \\
\text { 女性 } 30.0 \sim 45.0 \%\end{array}$ & \\
\hline コレステロール & $140 \sim 240 \mathrm{mg} / \mathrm{dl}$ & \multirow{5}{*}{$\begin{array}{l}\text { 酵素法 } \\
\text { 同 上 } \\
\text { 同 上: } \\
\text { BCG 法 } \\
\text { 酵素法 }\end{array}$} \\
\hline 中性脂肪 & $140 \mathrm{mg} / \mathrm{dl}$ 以下 & \\
\hline 酸 & $\begin{array}{l}\text { 男性 } 6.5 \mathrm{mg} / \mathrm{dl} \text { 以下 } \\
\text { 女性 } 5.5 \mathrm{mg} / \mathrm{dl} \text { 以下 }\end{array}$ & \\
\hline アルブミン & $3.5 \mathrm{~g} / \mathrm{dl}$ 以上: & \\
\hline コリンエステラーゼ & $0.61 \Delta \mathrm{pH}$ 以上 & \\
\hline 肥 満 度 & \multicolumn{2}{|c|}{$\begin{array}{lrl}\text { や } & \text { せ }:-11 \% \text { 以下 } & \\
\text { 正 常 }:-10 \% \sim+10 \% & \text { 箕輪氏 } \\
\text { 肥満傾向 } & \text { : }+11 \% \sim+19 \% & \text { 標準体重 } \\
\text { 肥 満 }\end{array}$} \\
\hline 高 血 圧 & \multicolumn{2}{|c|}{$\begin{array}{l}\text { 収縮期圧：160 mm Hg 以上:あるいは } \\
\text { 拡張期压： } 95 \mathrm{~mm} \mathrm{Hg} \text { 以上: }\end{array}$} \\
\hline $\begin{array}{l}\text { 心電図虚血 } \\
\text { 性変化 }\end{array}$ & \multicolumn{2}{|c|}{ ミネソタコード： $\begin{array}{l}1-1-1 \sim 1-3-6 \\
4-1 \sim 4-3,5-1 \sim 5 \sim 4\end{array}$} \\
\hline $\begin{array}{l}\text { 耐糖能分類 } \\
\text { (50g OGTT) }\end{array}$ & \multicolumn{2}{|c|}{ 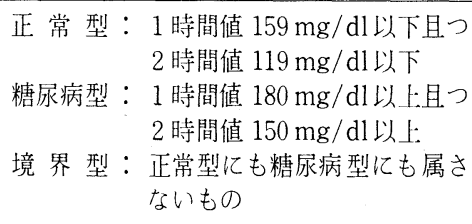 } \\
\hline
\end{tabular}


た。なお各項目の測定法並びに正常值は表 1 に一括提 示した。

（2）健康を自認しているものの中にも医学的検査を 行なってみると表 2 に示したよらに低アルブミン血症 を除く各項目にある程度の異常がみられるが，その中 でも境界型糖尿病は男女ともかなり高率であり，また
血清コリンェステラーゼ低下を示したものが男女とも 高率にみられた。対照として昭和 52 年度に実施じた広 島県全県下にわたる検診成績（治療中のものも含反対 象は30才代より60才代とした）を右端に示したが，上 記境界型糖尿病並びに血清コリンェステラーゼ低下を 示すもの以外は男女とも対照より低率であった。

表 2. 異常頻度性別年代別分類

\begin{tabular}{|c|c|c|c|c|c|c|c|c|c|c|c|c|}
\hline 代 & \multicolumn{2}{|c|}{30 才代 } & \multicolumn{2}{|c|}{40 才代 } & \multicolumn{2}{|c|}{50 才代 } & \multicolumn{2}{|c|}{60 才代 } & \multicolumn{2}{|c|}{ 計 } & \multicolumn{2}{|c|}{$\begin{array}{ll}\text { 対照 } & 30 \text { 垈代 } \\
\end{array}$} \\
\hline 性別 & 男 & 女 & 男 & 女 & 男 & 女 & 男 & 女 & 男 & 女 & 男 & 女 \\
\hline 症 例 数 & 14 & 32 & 50 & 58 & 62 & 66 & 41 & 31 & 167 & 187 & 1,252 & 1,796 \\
\hline やせ（-11\%以下） & $\begin{array}{c}1 \\
(7.1)\end{array}$ & $\begin{array}{c}2 \\
(6.3)\end{array}$ & 0 & $\begin{array}{c}6 \\
(10.3)\end{array}$ & $\begin{array}{c}3 \\
(4.8)\end{array}$ & $\begin{array}{c}8 \\
(12.1)\end{array}$ & $\begin{array}{c}5 \\
(12.2)\end{array}$ & $\begin{array}{c}6 \\
(19.4)\end{array}$ & $\begin{array}{c}9 \\
(5.4)\end{array}$ & $\begin{array}{c}22 \\
(11.8)\end{array}$ & $\begin{array}{c}81 \\
(6.5)\end{array}$ & $\begin{array}{c}200 \\
(11.1)\end{array}$ \\
\hline $\begin{array}{l}\text { 肥満傾向 } \\
\qquad(+11 \sim+19 \%)\end{array}$ & $\begin{array}{c}1 \\
(7.1)\end{array}$ & $\begin{array}{c}2 \\
(6.3)\end{array}$ & $\begin{array}{c}8 \\
(16.0)\end{array}$ & $\begin{array}{c}13 \\
(22.1)\end{array}$ & $\begin{array}{c}5 \\
(8.1)\end{array}$ & $\begin{array}{l}11 \\
(7.3)\end{array}$ & $\begin{array}{c}4 \\
(9.8)\end{array}$ & $\begin{array}{c}3 \\
(9.7)\end{array}$ & $\begin{array}{c}18 \\
(10.8)\end{array}$ & $\begin{array}{c}29 \\
(15.5)\end{array}$ & $\begin{array}{c}245 \\
(19.6)\end{array}$ & $\begin{array}{c}312 \\
(17.4)\end{array}$ \\
\hline 肥満（+20\%以上） & $\begin{array}{c}2 \\
(14.3)\end{array}$ & $\begin{array}{c}7 \\
(21.9)\end{array}$ & $\begin{array}{c}10 \\
(20.0)\end{array}$ & $\begin{array}{c}4 \\
(6.9)\end{array}$ & $\begin{array}{c}8 \\
(12.9)\end{array}$ & $\begin{array}{c}4 \\
(6.1)\end{array}$ & $\begin{array}{c}5 \\
(12.2)\end{array}$ & $\left(\begin{array}{c}1 \\
(3.2)\end{array}\right.$ & $\begin{array}{c}25 \\
(15.0)\end{array}$ & $\begin{array}{c}16 \\
(8.6)\end{array}$ & $\begin{array}{c}217 \\
(17.3)\end{array}$ & $\begin{array}{c}276 \\
(15.4)\end{array}$ \\
\hline 圧 & $\begin{array}{c}1 \\
(7.1)\end{array}$ & 0 & $\begin{array}{c}3 \\
(6.0)\end{array}$ & $\begin{array}{c}4 \\
(6.9)\end{array}$ & $\begin{array}{c}10 \\
(16.1)\end{array}$ & $\begin{array}{c}10 \\
(15.2)\end{array}$ & $\begin{array}{c}9 \\
(22.0)\end{array}$ & $\begin{array}{c}8 \\
(25.8)\end{array}$ & $\begin{array}{c}23 \\
(13.8)\end{array}$ & $\begin{array}{c}22 \\
(11.8)\end{array}$ & $\begin{array}{c}207 \\
(16.5)\end{array}$ & $\begin{array}{c}262 \\
(14.6)\end{array}$ \\
\hline 白 & 0 & 0 & $\begin{array}{c}1 \\
(2.0)\end{array}$ & $\begin{array}{c}1 \\
(1.7)\end{array}$ & $\begin{array}{c}3 \\
(4.8)\end{array}$ & 0 & $\begin{array}{c}1 \\
(2.4)\end{array}$ & 0 & $\begin{array}{c}5 \\
(3.0)\end{array}$ & $\begin{array}{c}1 \\
(0.5)\end{array}$ & $\begin{array}{c}81 \\
(6.5)\end{array}$ & $\begin{array}{c}66 \\
(3.7)\end{array}$ \\
\hline 血 & 0 & $\begin{array}{c}3 \\
(9.4)\end{array}$ & 0 & $\begin{array}{c}3 \\
(5.2)\end{array}$ & 0 & $\begin{array}{c}3 \\
(4.5)\end{array}$ & $\begin{array}{c}1 \\
(2.4)\end{array}$ & 0 & $\begin{array}{c}1 \\
(0.6)\end{array}$ & $\begin{array}{c}9 \\
(4.8)\end{array}$ & $\begin{array}{c}22 \\
(1.8)\end{array}$ & $\begin{array}{l}122 \\
(6.8)\end{array}$ \\
\hline 高へマトクリット血症 & 0 & 0 & $\begin{array}{c}4 \\
(8.0)\end{array}$ & 0 & 0 & $\begin{array}{c}1 \\
(1.5)\end{array}$ & 0 & 0 & $\begin{array}{c}4 \\
(2.4)\end{array}$ & $\left(\begin{array}{c}1 \\
0.5)\end{array}\right.$ & $\begin{array}{c}48 \\
(3.8)\end{array}$ & $\begin{array}{c}31 \\
(1.7)\end{array}$ \\
\hline \begin{tabular}{l|ll} 
耐糖能 & 境 界 型
\end{tabular} & $\begin{array}{c}2 \\
(14.3)\end{array}$ & $\begin{array}{c}8 \\
(25.0)\end{array}$ & $\begin{array}{c}21 \\
(42.0)\end{array}$ & $\begin{array}{c}22 \\
(37.9)\end{array}$ & $\begin{array}{c}21 \\
(33.9)\end{array}$ & $\begin{array}{c}30 \\
(45.5)\end{array}$ & $\begin{array}{c}29 \\
(70.7)\end{array}$ & $\begin{array}{c}24 \\
(77.4)\end{array}$ & $\begin{array}{c}73 \\
(43.7)\end{array}$ & $\begin{array}{c}84 \\
(44.9)\end{array}$ & $\begin{array}{c}564 \\
(45.0)\end{array}$ & $\begin{array}{c}748 \\
(41.6)\end{array}$ \\
\hline 障 害 $\mid$ 糖 尿 病 型 & 0 & $\left(\begin{array}{c}1 \\
(3.1)\end{array}\right.$ & $\begin{array}{c}3 \\
(6.0)\end{array}$ & $\begin{array}{c}6 \\
(10.3)\end{array}$ & $\begin{array}{c}6 \\
(9.7)\end{array}$ & $\begin{array}{c}7 \\
(10.6)\end{array}$ & $\begin{array}{c}2 \\
(4.9)\end{array}$ & $\left(\begin{array}{c}1 \\
(3.2)\end{array}\right.$ & $\begin{array}{l}11 \\
(6.6)\end{array}$ & $\begin{array}{l}15 \\
(8.0)\end{array}$ & $\begin{array}{c}110 \\
(8.8)\end{array}$ & $\begin{array}{c}154 \\
(8.6)\end{array}$ \\
\hline 高コレステロール血症 & 0 & 0 & $\begin{array}{c}3 \\
(6.0)\end{array}$ & $\begin{array}{c}2 \\
(3.4)\end{array}$ & $\begin{array}{c}3 \\
(4.8)\end{array}$ & $\begin{array}{c}9 \\
(13.6)\end{array}$ & $\begin{array}{c}4 \\
(9.8)\end{array}$ & $\begin{array}{c}2 \\
(6.5)\end{array}$ & $\begin{array}{l}10 \\
(6.0)\end{array}$ & $\begin{array}{c}13 \\
(7.0)\end{array}$ & $\begin{array}{c}161 \\
(12.9)\end{array}$ & $\begin{array}{c}272 \\
(15.1)\end{array}$ \\
\hline 低コレステロール血症 & $\begin{array}{c}1 \\
(7.1)\end{array}$ & $\begin{array}{c}5 \\
(15.6)\end{array}$ & $\begin{array}{c}2 \\
(4.0)\end{array}$ & $\begin{array}{c}5 \\
(8.6)\end{array}$ & $\begin{array}{c}2 \\
(3.2)\end{array}$ & 0 & $\begin{array}{c}4 \\
(9.8)\end{array}$ & $\begin{array}{c}3 \\
(9.7)\end{array}$ & $\begin{array}{c}9 \\
(5.4)\end{array}$ & $\begin{array}{l}13 \\
(7.0)\end{array}$ & $\begin{array}{c}70 \\
(5.6)\end{array}$ & $\begin{array}{c}88 \\
(5.0)\end{array}$ \\
\hline 高中性脂肪血症 & $\begin{array}{c}1 \\
(7.1)\end{array}$ & $\begin{array}{c}2 \\
(6.3)\end{array}$ & $\begin{array}{c}11 \\
(22.0)\end{array}$ & $\begin{array}{c}3 \\
(5.2)\end{array}$ & $\begin{array}{c}9 \\
(14.5)\end{array}$ & $\begin{array}{c}9 \\
(13.6)\end{array}$ & $\begin{array}{c}7 \\
(17.1)\end{array}$ & $\begin{array}{c}5 \\
(16.1)\end{array}$ & $\begin{array}{c}28 \\
(16.8)\end{array}$ & $\begin{array}{c}19 \\
(10.2)\end{array}$ & $\begin{array}{c}259 \\
(20.7)\end{array}$ & $\begin{array}{c}249 \\
(13.9)\end{array}$ \\
\hline 高 尿 酸 血 症 & 0 & 0 & $\begin{array}{c}2 \\
(4.0)\end{array}$ & 0 & 0 & 0 & $\begin{array}{c}1 \\
(2.4)\end{array}$ & 0 & $\begin{array}{c}3 \\
(1.8)\end{array}$ & 0 & $\begin{array}{c}56 \\
(4.5)\end{array}$ & $\begin{array}{c}15 \\
(0.8)\end{array}$ \\
\hline 低アルブミン血症 & 0 & 0 & 0 & 0 & 0 & 0 & 0 & 0 & 0 & 0 & $\begin{array}{c}3 \\
(0.2)\end{array}$ & 0 \\
\hline 血清コリンエステラーゼ倩 & $\begin{array}{c}2 \\
(14.3)\end{array}$ & $\begin{array}{c}6 \\
(18.8)\end{array}$ & $\begin{array}{c}4 \\
(8.0)\end{array}$ & $\begin{array}{c}19 \\
(32.8)\end{array}$ & $\begin{array}{c}12 \\
(19.4)\end{array}$ & $\begin{array}{c}12 \\
(18.2)\end{array}$ & $\begin{array}{c}7 \\
(17.1)\end{array}$ & $\begin{array}{c}4 \\
(12.9)\end{array}$ & $\begin{array}{c}25 \\
(15.0)\end{array}$ & $\begin{array}{c}41 \\
(21.9)\end{array}$ & $\begin{array}{l}108 \\
(8.6)\end{array}$ & $\begin{array}{l}136 \\
(7.6)\end{array}$ \\
\hline
\end{tabular}

次に調査項目の平均值および標準偏差を表 3 に示し た。平均值でみる限り各項目とも正常と考えられる範 井内にあるが, 収縮期血圧, 経口50 g ブドー糖負荷後 1 時間および 2 時間血糖值, コレステロール, 中性脂 肪, コリンエステラーゼの標準偏差はかなり大きい値 が示された。
（3）小括 以上第 1 年度の成績について述べたが， 自ら健康と考えているものの中にもある程度の異常が 存在するが，対照と比較した場合その率は低いことが わかった。ただし境界型糖尿病は対照とほぼ同程度に みられること並びにコリンェステラーゼ低下を示すす のが対照よりかなり高率にみられたことは，一考すべ 
表 3. 調査項目の年令別・性別平均值一覧

\begin{tabular}{|c|c|c|c|c|c|c|c|c|c|c|}
\hline 年 & \multicolumn{2}{|r|}{ 令 } & \multicolumn{2}{|c|}{30 才 代 } & \multicolumn{2}{|c|}{40 才代 } & \multicolumn{2}{|c|}{50 才 代 } & \multicolumn{2}{|c|}{60 才代 } \\
\hline 性 & & 別 & 男 & 女 & 男 & 女 & 男 & 女 & 男 & 女 \\
\hline 症 & 例 & 数 & 14 & 32 & 50 & 58 & 62 & 66 & 41 & 31 \\
\hline 肥 満 & 度 & $(\%)$ & $\begin{array}{r}6.2 \\
+8.9\end{array}$ & $\begin{array}{r}6.3 \\
\pm 13.6\end{array}$ & $\begin{array}{r}8.7 \\
\pm 10.8\end{array}$ & $\begin{array}{r}3.8 \\
\pm 11.6\end{array}$ & $\begin{array}{r}4.1 \\
\pm 10.5\end{array}$ & $\begin{array}{r}2.2 \\
\pm 11.2\end{array}$ & $\begin{array}{r}3.1 \\
\pm 13.1\end{array}$ & $\begin{array}{r}-1.5 \\
\pm 11.2\end{array}$ \\
\hline \multirow{2}{*}{ 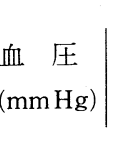 } & 収 縮 & 期 圧 & $\begin{array}{r}127.9 \\
\pm 12.2\end{array}$ & $\begin{array}{r}117.7 \\
\pm 11.2\end{array}$ & $\begin{array}{r}127.0 \\
\pm 17.5\end{array}$ & $\begin{array}{r}126.4 \\
\pm 16.9\end{array}$ & $\begin{array}{r}129.7 \\
\pm 21.2\end{array}$ & $\begin{array}{r}133.6 \\
\pm 22.2\end{array}$ & $\begin{array}{r}139.6 \\
\pm 22.4\end{array}$ & $\begin{array}{r}145.6 \\
\pm 24.8\end{array}$ \\
\hline & 拡 張 & 期 圧 & $\begin{aligned} & 74.3 \\
\pm & 7.0\end{aligned}$ & $\begin{aligned} & 66.2 \\
\pm & 7.3\end{aligned}$ & $\begin{array}{r}73.1 \\
\pm 10.2\end{array}$ & $\begin{array}{r}73.7 \\
\pm 11.4\end{array}$ & $\begin{array}{r}75.4 \\
\pm 11.8\end{array}$ & $\begin{array}{r}75.4 \\
\pm 10.7\end{array}$ & $\begin{array}{r}76.6 \\
\pm 10.4\end{array}$ & $\begin{array}{l}78.5 \\
\pm 9.3\end{array}$ \\
\hline 血 & 素 & $(\mathrm{g} / \mathrm{dl})$ & $\begin{aligned} & 14.6 \\
\pm & 1.2\end{aligned}$ & $\begin{aligned} & 12.9 \\
\pm & 1.3\end{aligned}$ & $\begin{aligned} & 15.1 \\
\pm & 1.0\end{aligned}$ & $\begin{aligned} & 12.6 \\
\pm & 1.1\end{aligned}$ & $\begin{array}{l}14.4 \\
\pm 0.9\end{array}$ & $\begin{array}{c}12.6 \\
\pm 1.2\end{array}$ & $\begin{aligned} & 14.2 \\
\pm & 1.3\end{aligned}$ & $\begin{aligned} & 12.7 \\
\pm & 0.8\end{aligned}$ \\
\hline \multicolumn{2}{|c|}{ ヘマトクリット } & $(\%)$ & $\begin{aligned} & 43.3 \\
\pm & 4.1\end{aligned}$ & $\begin{aligned} & 38.5 \\
\pm & 3.3\end{aligned}$ & $\begin{aligned} & 45.0 \\
\pm & 2.9\end{aligned}$ & $\begin{aligned} & 37.6 \\
\pm & 3.0\end{aligned}$ & $\begin{aligned} & 42.7 \\
\pm & 2.5\end{aligned}$ & $\begin{aligned} & 37.9 \\
\pm & 2.8\end{aligned}$ & $\begin{aligned} & 42.3 \\
\pm & 4.0\end{aligned}$ & $\begin{aligned} & 38.2 \\
\pm & 2.5\end{aligned}$ \\
\hline \multirow{3}{*}{$\begin{array}{l}\text { GTT } \\
(\mathrm{mg} / \mathrm{dl})\end{array}$} & 空 腹 & 時 值 & $\begin{array}{r}82.0 \\
\pm 10.7\end{array}$ & $\begin{aligned} & 81.0 \\
\pm & 8.4\end{aligned}$ & $\begin{array}{r}85.2 \\
\pm 18.5\end{array}$ & $\begin{array}{r}83.3 \\
\pm 12.3\end{array}$ & $\begin{array}{r}88.2 \\
\pm 11.7\end{array}$ & $\begin{array}{r}86.6 \\
\pm 10.8\end{array}$ & $\begin{aligned} 87.5 \\
\pm 9.8\end{aligned}$ & $\begin{aligned} & 89.3 \\
\pm & 9.5\end{aligned}$ \\
\hline & 1 時 & 間 值 & $\begin{array}{r}133.0 \\
\pm 47.2\end{array}$ & $\begin{array}{r}138.2 \\
\pm 40.2\end{array}$ & $\begin{array}{r}169.1 \\
\pm 55.4\end{array}$ & $\begin{array}{r}153.8 \\
\pm 49.3\end{array}$ & $\begin{array}{r}159.8 \\
\pm 44.9\end{array}$ & $\begin{array}{r}163.1 \\
\pm 45.0\end{array}$ & $\begin{array}{r}180.7 \\
\pm 35.6\end{array}$ & $\begin{array}{r}182.9 \\
\pm 39.2\end{array}$ \\
\hline & 2 時 & 間 值 & $\begin{array}{r}81.1 \\
\pm 21.8\end{array}$ & $\begin{array}{r}94.5 \\
\pm 24.9\end{array}$ & $\begin{array}{r}94.0 \\
\pm 32.3\end{array}$ & $\begin{array}{r}107.1 \\
\pm 38.7\end{array}$ & $\begin{array}{r}95.8 \\
\pm 38.2\end{array}$ & $\begin{array}{r}104.2 \\
\pm 31.2\end{array}$ & $\begin{array}{r}104.2 \\
\pm 33.1\end{array}$ & $\begin{array}{r}97.5 \\
\pm 28.3\end{array}$ \\
\hline \multicolumn{2}{|c|}{ コレステロール } & $(\mathrm{mg} / \mathrm{dl})$ & $\begin{array}{r}168.7 \\
\pm 27.0\end{array}$ & $\begin{array}{r}164.4 \\
\pm 28.5\end{array}$ & $\begin{array}{r}191.1 \\
\pm 35.1\end{array}$ & $\begin{array}{r}179.0 \\
\pm 28.1\end{array}$ & $\begin{array}{r}186.0 \\
\pm 31.2\end{array}$ & $\begin{array}{r}194.1 \\
\pm 34.0\end{array}$ & $\begin{array}{r}187.2 \\
\pm 37.5\end{array}$ & $\begin{array}{r}186.4 \\
\pm 31.5\end{array}$ \\
\hline \multicolumn{2}{|c|}{ 中 性 脂 肪 } & $(\mathrm{mg} / \mathrm{dl})$ & $\begin{array}{r}90.5 \\
\pm 28.7\end{array}$ & $\begin{array}{r}79.3 \\
\pm 31.0\end{array}$ & $\begin{array}{r}126.6 \\
\pm 80.9\end{array}$ & $\begin{array}{r}89.4 \\
\pm 29.3\end{array}$ & $\begin{array}{r}104.9 \\
\pm 44.0\end{array}$ & $\begin{array}{r}102.3 \\
\pm 36.8\end{array}$ & $\begin{array}{r}111.4 \\
\pm 66.2\end{array}$ & $\begin{array}{r}102.1 \\
\pm 47.7\end{array}$ \\
\hline 尿 & 酸 & $(\mathrm{mg} / \mathrm{dl})$ & $\begin{aligned} & 4.2 \\
\pm & 0.9\end{aligned}$ & $\begin{aligned} & 3.4 \\
\pm & 0.6\end{aligned}$ & $\begin{aligned} & 4.4 \\
& \pm 1.1\end{aligned}$ & $\begin{aligned} & 3.3 \\
\pm & 0.5\end{aligned}$ & $\begin{aligned} & 4.0 \\
\pm & 0.9\end{aligned}$ & $\begin{aligned} & 3.5 \\
\pm & 0.7\end{aligned}$ & $\begin{aligned} & 4.1 \\
\pm & 1.1\end{aligned}$ & $\begin{aligned} & 3.4 \\
\pm & 0.7\end{aligned}$ \\
\hline \multicolumn{2}{|c|}{ アルブミン } & $(\mathrm{g} / \mathrm{dl})$ & $\begin{aligned} & 4.5 \\
\pm & 0.3\end{aligned}$ & $\begin{aligned} & 4.3 \\
\pm & 0.2\end{aligned}$ & $\begin{aligned} & 4.4 \\
\pm & 0.3\end{aligned}$ & $\begin{aligned} & 4.2 \\
\pm & 0.2\end{aligned}$ & $\begin{aligned} & 4.3 \\
& \pm 0.2\end{aligned}$ & $\begin{aligned} & 4.3 \\
\pm & 0.3\end{aligned}$ & $\begin{aligned} & 4.2 \\
\pm & 0.3\end{aligned}$ & $\begin{aligned} & 4.3 \\
\pm & 0.2\end{aligned}$ \\
\hline \multicolumn{2}{|c|}{ コリンエステラーゼ } & $(\Delta \mathrm{pH})$ & $\begin{aligned} & 0.82 \\
\pm & 0.20\end{aligned}$ & $\begin{array}{r}0.76 \\
\pm 0.21\end{array}$ & $\begin{aligned} & 0.86 \\
\pm & 0.23\end{aligned}$ & $\begin{array}{r}0.75 \\
\pm 0.21\end{array}$ & $\begin{aligned} & 0.82 \\
\pm & 0.20\end{aligned}$ & $\begin{array}{r}0.85 \\
\pm 0.25\end{array}$ & $\begin{aligned} & 0.85 \\
\pm & 0.19\end{aligned}$ & $\begin{array}{r}0.82 \\
\pm 0.19\end{array}$ \\
\hline
\end{tabular}

平均值士標準偏差

き問題であろら。境界型糖尿病については近年余り問 題にすべきではないとの考学があるが，コリンェステ ラーゼ低下を示すものが高率にみられた点については 対象選択の問題もあ万らが, 農薬散布との関連も充分 考えねばならないと思う。

今回の調査では貧血，糖尿病，特に経口 $50 \mathrm{~g}$ ブドー 糖負荷後 2 時間血糖が $200 \mathrm{mg} / \mathrm{d} \ell$ 以上の症例は対照 より明らかに少なく，また高へマトクリット血症，高 コレステロール血症, 低コレステロール血症, 高中性 脂肪血症, 高尿酸血症等は動脈硬化性血管障害の Risk factor と考えられているものであり，これらは就しろ 積極的に発見するよらつとむべきであると考えられる ので，現在用いている表 1 に示した規準は健康の基礎 的指標としての血液性状值として充分使用し得るので はないかと考えている。
2. 第 2 年度研究

(1) 対象は広島県全域にわたる自ら健康と考えてい る農業従事者で30才代より50才代にわたる男性77人, 女性 110 人であり, 肥満度, 血圧, 心電図, 血色素, 一

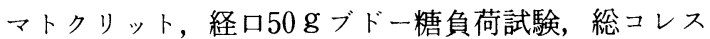
テロール, 中性脂肪, 尿酸, 血清アルブミン, 血清コ リンェステラーゼについて第 1 年度および第 2 年度と もほぼ同一時期に測定し, 表 1 亿示した規準に従って 第 1 年度と第 2 年度の異常頻度を比較した。

その成績は表 4 に一括表示した。

総括的にみると肥満, 高血圧, 高へマトクリット血 症では第 1 年度と第 2 年度の間に殆ど変化はみられな かった。

心電図虚血性変化は男女とも第 1 年度より第 2 年度 の方がやや高率になっており，40才代の男女，50才代 
表 4. 異常頻度の経年別検討

\begin{tabular}{|c|c|c|c|c|c|c|c|c|c|c|c|}
\hline \multirow{2}{*}{\multicolumn{2}{|c|}{$\begin{array}{cc}\text { 年 } & \text { 代 } \\
\text { 性 } & \text { 別 }\end{array}$}} & \multicolumn{2}{|c|}{30 才代 } & \multicolumn{2}{|c|}{40 才代 } & \multicolumn{2}{|c|}{50 才代 } & \multicolumn{2}{|c|}{ 計 } & \multicolumn{2}{|c|}{ 対 照 (30才代 50才代) } \\
\hline & & 男 & 女 & 男 & 女 & 男 & 女 & 男 & 女 & 男 & 女 \\
\hline & 症 例 数 & 15 & 20 & 30 & 52 & 32 & 38 & 77 & 110 & 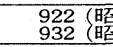 & 2) 1478 \\
\hline \multirow{3}{*}{ 肥 } & \multirow[b]{2}{*}{ I $\{$ 肥満傾向 } & 0 & $1(5.0)$ & $3(10.0)$ & $6(11.5)$ & 0 & $5(13.2)$ & $3(3.9)$ & $12(10.9)$ & $42(4.6)$ & $151(10.2)$ \\
\hline & & $2(13.3)$ & $3(15.0)$ & $7(23.3)$ & $8(15.6)$ & $5(15.6)$ & $5(13.2)$ & $14(18.2)$ & $16(14.5)$ & $192(20.8)$ & 247 (16.7) \\
\hline & 肥 & $2(13.3)$ & $1(5.0)$ & $3(10.0)$ & $4(7.7)$ & $5(15.6)$ & $5(13.2)$ & $10(13.0)$ & $10(9.1)$ & $176(19.1)$ & $233(15.8)$ \\
\hline 満 & \multirow{2}{*}{ II 肥満 傾 向 } & 0 & $3(15.0)$ & $3(10.0)$ & $3(5.8)$ & 0 & $4(10.5)$ & $3(3.9)$ & $10(9.1)$ & $50(5.4)$ & $149(9.1)$ \\
\hline \multirow[t]{2}{*}{ 度 } & & $1(6.7)$ & $2(10.0)$ & $7(23.3)$ & $9(17.3)$ & $9(28.1)$ & $7(22.1)$ & $17(22.1)$ & $18(16.4)$ & $192(20.6)$ & $249(15.2)$ \\
\hline & & $3(20.0)$ & $2(10.0)$ & $4(13.3)$ & $4(7.7)$ & $5(15.6)$ & $4(10.5)$ & $12(15.6)$ & $10(9.1)$ & $170(18.2)$ & $285(17.4)$ \\
\hline \multirow{2}{*}{\multicolumn{2}{|c|}{ 高 血 圧 $\left\{\begin{array}{l}1 \\
\text { II }\end{array}\right.$}} & $1(6.7)$ & 0 & $3(10.0)$ & $4(7.7)$ & $6(18.8)$ & $7(18.4)$ & $10(13.0)$ & $11(10.0)$ & $128(13.9)$ & $166(12.2)$ \\
\hline & & $1(6.7)$ & 0 & $2(6.7)$ & $5(9.6)$ & $7(21.9)$ & $8(21.1)$ & $10(13.0)$ & $13(11.8)$ & $102(10.9)$ & $169(10.0)$ \\
\hline \multirow{2}{*}{\multicolumn{2}{|c|}{ 心電図虚血性変化 $\left\{\begin{array}{l}\text { I } \\
\text { II }\end{array}\right.$}} & $1(6.7)$ & 0 & 0 & $4(7.7)$ & $2(6.3)$ & $1(2.6)$ & $3(3.9)$ & $5(4.5)$ & $41(4.4)$ & $112(7.6)$ \\
\hline & & $1(6.7)$ & $1(5.0)$ & $2(6.7)$ & $6(11.5)$ & $2(6.3)$ & $3(7.9)$ & $5(6.5)$ & $10(9.1)$ & $43(4.6)$ & $134(8.2)$ \\
\hline \multirow{2}{*}{\multicolumn{2}{|c|}{ 貧 }} & 0 & $4(20.0)$ & 0 & $4(7.7)$ & 0 & $1(2.6)$ & 0 & $9(8.2)$ & $11(1.2)$ & $106(7.2)$ \\
\hline & & 0 & $2(10.0)$ & 0 & $3(5.8)$ & 0 & $2(5.3)$ & 0 & $7(6.4)$ & $13(1.4)$ & $78(4.8)$ \\
\hline \multirow{2}{*}{\multicolumn{2}{|c|}{ 高へマトクリット血症 $\left\{\begin{array}{l}\text { I } \\
\text { II }\end{array}\right.$}} & 0 & 0 & 0 & 0 & 0 & $1(2.6)$ & 0 & $1(0.9)$ & $32(3.4)$ & $25(1.7)$ \\
\hline & & 0 & 0 & $1(3.3)$ & 0 & 0 & $2(5.3)$ & $1(1.3)$ & $2(1.8)$ & $40(4.3)$ & $28(1.7)$ \\
\hline \multirow{4}{*}{\multicolumn{2}{|c|}{ 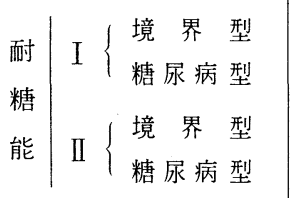 }} & $7(46.7)$ & $8(40.0)$ & $14(46.7)$ & $32(61.5)$ & $14(43.7)$ & $20(52.6)^{*}$ & $35(45.5)$ & $60(54.5)$ & $386(41.9)$ & $576(39.0)$ \\
\hline & & 0 & 0 & $1(3.3)$ & $1(1.9)$ & $3(9.4)$ & $1(2.6)$ & $4(5.2)$ & $2(1.8)$ & $64(6.9)$ & $105(7.1)$ \\
\hline & & $3(20.0)$ & $6(30.0)$ & $11(36.7)$ & $28(53.8)$ & $14(43.7)$ & $19(30.0)$ & $28(36.4)$ & $53(48.2)$ & $398(42.7)$ & $636(38.9)$ \\
\hline & & 0 & 0 & $1(3.3)$ & $1(1.9)$ & $2(6.3)$ & $2(5.3)$ & $3(3.9)$ & $3(2.7)$ & $55(5.9)$ & $106(6.5)$ \\
\hline \multirow{2}{*}{\multicolumn{2}{|c|}{ 高コレステロール血症 $\left\{\begin{array}{l}\text { I } \\
\text { II }\end{array}\right.$}} & $3(20.0)$ & 0 & $2(6.7)$ & $4(7.7)$ & $1(3.1)$ & $4(10.5)$ & $6(7.8)$ & $8(7.3)$ & 117 (12.7) & $189(12.8)$ \\
\hline & & $4(26.7)$ & 0 & $5(16.7)$ & $5(9.6)$ & $5(15.6)$ & 7 (18.4) & $14(18.2)$ & $12(10.9)$ & $157(16.7)$ & $231(14.1)$ \\
\hline \multirow{2}{*}{\multicolumn{2}{|c|}{ 低コレステロール血症 $\left\{\begin{array}{l}I \\
\text { II }\end{array}\right.$}} & 0 & $3(15.0)$ & 0 & $7(13.5)$ & $2(6.3)$ & $3(7.9)$ & $2(2.6)$ & $13(11.8)$ & $46(5.0)$ & $80(5.4)$ \\
\hline & & 0 & $3(15.0)$ & $1(3.3)$ & $1(1.9)$ & $1(3.1)$ & $1(2.6)$ & $2(2.6)$ & $5(4.5)$ & $39(4.2)$ & $71(4.3)$ \\
\hline \multirow{2}{*}{\multicolumn{2}{|c|}{ 高中性脂肪血症 $\left\{\begin{array}{l}\text { I } \\
\text { II }\end{array}\right.$}} & $4(26.7)$ & 0 & $8(26.7)$ & $1(1.9)$ & $4(12.5)$ & $4(10.5)$ & $16(20.8)$ & $5(4.5)$ & $203(22.0)$ & 189 (12.8) \\
\hline & & $4(26.7)$ & 0 & $9(30.0)$ & $4(30.0)$ & $7(21.9)$ & $4(10.5)$ & $20(26.0)$ & $8(7.3)$ & $224(24.0)$ & $230(14.1)$ \\
\hline \multirow{2}{*}{\multicolumn{2}{|c|}{ 高尿 酸 血 症 $\left\{\begin{array}{l}\text { I } \\
\text { II }\end{array}\right.$}} & 0 & 0 & $5(16.7)$ & $2(3.8)$ & $2(6.3)$ & $1(2.6)$ & & $3(2.7)$ & $49(5.3)$ & $10(0.7)$ \\
\hline & & $1(6.7)$ & 0 & $1(3.3)$ & 0 & 0 & $1(2.6)$ & $2(2.6)$ & $1(0.9)$ & $49(5.3)$ & $9(0.6)$ \\
\hline \multirow{2}{*}{\multicolumn{2}{|c|}{ 低アルブミン血症 $\left\{\begin{array}{l}I \\
\text { II }\end{array}\right.$}} & 0 & 0 & 0 & 0 & 0 & 0 & 0 & 0 & $1(0.1)$ & 0 \\
\hline & & 0 & 0 & 0 & 0 & 0 & 0 & 0 & 0 & 0 & $1(0.1)$ \\
\hline \multirow{2}{*}{\multicolumn{2}{|c|}{ 低コリンエステラーゼ $\left\{\begin{array}{l}\text { I } \\
\text { 血症 }\end{array}\right.$}} & 0 & $3(15.0)$ & $1(3.3)$ & $7(13.5)$ & $4(12.5)$ & $1(2.6)$ & $5(6.5)$ & $11(10.0)$ & $66(7.2)$ & $113(7.6)$ \\
\hline & & 0 & $4(20.0)$ & $6(20.0)^{*}$ & $12(23.1)$ & $4(12.5)$ & $2(5.3)$ & $10(13.0)$ & $18(16.4)$ & $61(6.5)$ & $119(7.2)$ \\
\hline
\end{tabular}

(註) $\mathrm{I} ：$ 第 1 年度, II : 第 2 年度, （）は\%, $* \mathrm{P}<0.05$

の女性の変化が影響したものと思われる。

貧血は, 第 1 年度より第 2 年度の方がやや低率で改 善傾向がみられる。

$50 \mathrm{~g}$ 経ロブドー糖負荷試験では境界型糖尿病は男女 とも第 1 年度に比し第 2 年度ではかなり低率になって いるが，糖尿病型では大きな变化はみられなかった。
高コレステロール血症は男女とも第 1 年度より第 2 年度の方が高率となっており，40才代の男性および50 才代の男女の変化が影響しているものと考えられる。 低コレステロール血症は男性では変化なく，女性で は第 1 年度より第 2 年度の方が低率であった。 高中性脂肪血症も男女之も第 1 年度上り第 2 年度の 
方が高率であったが，これは40才代の女性，50才代の 男性の変化が影響したと思われる。

高尿酸血症は第 1 年度より第 2 年度の方が低率之 なっており，各年代とも改善傾向がみられた。

低アルブミン血症は第 1 年度, 第 2 年度とも調査対 象には全くみられなかった。

血清コリンェルテラーゼ低下を示したものは第 1 年 度より第 2 年度の方が高率であり, 40 才代男女の変化 が影響したものと思われた。

（2）各調查項目平均値, 標準偏差を性別, 年代別, 経時別に分類して表 5 に一括表示した。

血色素量, ヘマトクリット, 空腹時血糖, 中性脂肪, アルブミンには第 1 年度と第 2 年度の間に大きな変化 はみられなかった。

経口50 g ブドー糖負荷 1 時間後の血糖では 30 才代の 男性において第 1 年度より第 2 年度の方がかなり低下 しており，2 時間後の血糖では 40 才代の男性，50才代
の男女において第 1 年度より第 2 年度の方がやや高値 を示していた。

コレステロールでは各年代男女とも第 1 年度より第 2 年度の方がやや高値を呈しており, 尿酸では $30 才$ 才代 の男性を除く各年代の男女とも，また血清コリンエス テラーゼでは各年代の男女をも第 1 年度より第 2 年度 の方が低值を示していた。

（3）各調査項目について個人別の経年変化を表 6 に 一括表示した。

肥満度についてみると約 $60 \%$ は正常で経過している が, 肥満のままで経過したものもかなりみられ, 肥満 に進展したものは男女とも5〜6\%あった。

血圧では男女とも正常のまま経過したものが大半で あったが，高血圧に進展したもの，高血圧が改善した もの並びに高血圧のまま経過したものも少数みられ た。

心電図虚血性変化では大多数のものは著変なく経過

表 5. 平均值の経年別検討

\begin{tabular}{|c|c|c|c|c|c|c|c|c|c|}
\hline \multirow{2}{*}{\multicolumn{3}{|c|}{$\begin{array}{cc}\text { 年 } & \text { 代 } \\
\text { 性 } & \text { 別 } \\
\end{array}$}} & & \multicolumn{2}{|c|}{30 才代 } & \multicolumn{2}{|c|}{40 才代 } & \multicolumn{2}{|c|}{50 才代 } \\
\hline & & & & 男 & 女 & 男 & 女 & 男 & 女 \\
\hline & 症 & 例 数 & & 15 & 20 & 30 & 52 & 32 & 38 \\
\hline \multirow{2}{*}{\multicolumn{4}{|c|}{ 血色 $\underset{(\mathrm{g} / \mathrm{dl})}{\text { 素 }}\left\{\begin{array}{l}\mathrm{I} \\
I I\end{array}\right.$}} & $15.0 \pm 0.97$ & $12.2 \pm 1.35$ & $14.9 \pm 0.97$ & $12.6 \pm 1.33$ & $14.6 \pm 0.88$ & $12.8 \pm 1.14$ \\
\hline & & & & $15.3 \pm 0.86$ & $12.5 \pm 1.16$ & $15.0 \pm 0.90$ & $12.6 \pm 1.37$ & $14.7 \pm 0.95$ & $12.9 \pm 1.11$ \\
\hline \multirow{2}{*}{\multicolumn{3}{|c|}{$\begin{array}{r}\text { ヘマトクリット } \\
(\%)\end{array}$}} & & $44.1 \pm 2.90$ & $36.1 \pm 3.39$ & $43.8 \pm 2.99$ & $37.4 \pm 3.29$ & $43.5 \pm 2.61$ & $38.1 \pm 3.05$ \\
\hline & & & & $45.5 \pm 2.21$ & $37.9 \pm 2.64$ & $44.9 \pm 2.80$ & $38.9 \pm 3.13$ & $44.4 \pm 2.72$ & $39.0 \pm 3.56$ \\
\hline \multirow{2}{*}{\multicolumn{3}{|c|}{$\begin{array}{r}\text { 空腹時血 糖 值 } \\
(\mathrm{mg} / \mathrm{dl})\end{array}$}} & & $90.1 \pm 12.6$ & $89.6 \pm 18.1$ & $84.6 \pm 7.7$ & $88.9 \pm 9.8$ & $86.3 \pm 11.9$ & $90.4 \pm 10.2$ \\
\hline & & & II & $84.4 \pm 13.0$ & $81.1 \pm 9.4$ & $86.1 \pm 8.9$ & $85.9 \pm 9.2$ & $86.9 \pm 8.8$ & $86.1 \pm 8.0$ \\
\hline \multirow{2}{*}{\multicolumn{4}{|c|}{$\begin{array}{l}50 \mathrm{~g} \text { OGTT1 時間 } \\
\text { 後血糖値 }(\mathrm{mg} / \mathrm{dl})\end{array}$}} & $151.8 \pm 53.0$ & $140.5 \pm 35.1$ & $162.2 \pm 46.0$ & $167.0 \pm 33.6$ & $169.8 \pm 42.3$ & $163.6 \pm 42.6$ \\
\hline & & & & $132.2 \pm 33.5$ & $144.4 \pm 42.2$ & $167.1 \pm 42.8$ & $157.9 \pm 35.5$ & $162.3 \pm 34.7$ & $157.1 \pm 43.4$ \\
\hline \multirow{2}{*}{\multicolumn{4}{|c|}{$\begin{array}{l}50 \mathrm{~g} \text { OGTT2 時間 } \\
\text { 後血糖傎 }(\mathrm{mg} / \mathrm{dl})\end{array}$}} & $87.1 \pm 22.8$ & $89.9 \pm 24.3$ & $81.6 \pm 27.7$ & $103.0 \pm 27.3$ & $97.8 \pm 41.3$ & $96.1 \pm 26.9$ \\
\hline & & & & $75.8 \pm 19.5$ & $87.6 \pm 25.7$ & $83.8 \pm 25.6$ & $106.8 \pm 23.9$ & $100.9 \pm 37.7$ & $103.0 \pm 31.2$ \\
\hline \multirow{2}{*}{\multicolumn{4}{|c|}{$\begin{array}{r}\text { コレステロール } \\
(\mathrm{mg} / \mathrm{dl})\end{array}$}} & $195.8 \pm 41.0$ & $158.9 \pm 27.7$ & $187.6 \pm 38.8$ & $184.2 \pm 36.7$ & $187.6 \pm 32.8$ & $202.3 \pm 43.8$ \\
\hline & & & & $209.9 \pm 44.8$ & $167.1 \pm 27.3$ & $197.0 \pm 40.7$ & $201.7 \pm 33.8$ & $194.9 \pm 36.7$ & $214.4 \pm 41.1$ \\
\hline \multirow[t]{2}{*}{ 中 } & & 脂 肪 & & $118.7 \pm 65.3$ & $72.8 \pm 22.2$ & $122.5 \pm 69.0$ & $80.5 \pm 25.0$ & $99.4 \pm 31.7$ & $91.3 \pm 39.3$ \\
\hline & & $(\mathrm{mg} / \mathrm{dl})$ & II & $124.9 \pm 64.5$ & $69.6 \pm 24.6$ & $120.0 \pm 60.9$ & $84.9 \pm 31.2$ & $99.2 \pm 45.3$ & $93.4 \pm 28.9$ \\
\hline \multirow[t]{2}{*}{ 尿 } & & & & $4.3 \pm 0.53$ & $2.9 \pm 0.57$ & $4.7 \pm 1.08$ & $3.3 \pm 0.88^{*}$ & $4.4 \pm 0.99$ & $3.7 \pm 0.73 *$ \\
\hline & & $(\mathrm{mg} / \mathrm{dl})$ & & $4.5 \pm 0.82$ & $2.7 \pm 0.62$ & $4.4 \pm 0.88$ & $2.8 \pm 0.68$ & $4.0 \pm 0.78$ & $3.1 \pm 0.72$ \\
\hline \multirow{2}{*}{\multicolumn{3}{|c|}{$\begin{array}{r}\text { 血清アルブミン } \\
(\mathrm{mg} / \mathrm{dl})\end{array}$}} & & $4.5 \pm 0.17$ & $4.3 \pm 0.19$ & $4.7 \pm 1.08$ & $4.4 \pm 0.20$ & $4.4 \pm 0.22$ & $4.4 \pm 0.18$ \\
\hline & & & & $4.5 \pm 0.20$ & $4.2 \pm 0.22$ & $4.4 \pm 0.88$ & $4.4 \pm 0.19$ & $4.5 \pm 0.29$ & $4.4 \pm 0.19$ \\
\hline \multirow{2}{*}{\multicolumn{4}{|c|}{$\begin{array}{c}\text { 血清コリンエステラーゼ } \\
(\Delta \mathrm{pH})\end{array}$}} & $0.94 \pm 0.14$ & $0.81 \pm 0.71$ & $0.89 \pm 0.13$ & $0.85 \pm 0.19$ & $0.93 \pm 0.23$ & $0.98 \pm 0.25$ \\
\hline & & & & $0.88 \pm 0.14$ & $0.73 \pm 0.12^{*}$ & $0.76 \pm 0.23^{*}$ & $0.75 \pm 0.20^{*}$ & $0.81 \pm 0.21^{*}$ & $0.87 \pm 0.20^{*}$ \\
\hline
\end{tabular}

(註) 平均值土標準偏差, I : 第 1 年度, II : 第 2 年度, $* \mathrm{P}<0.05$ 
表 6. 経年変化個人別検討

（）は\%

\begin{tabular}{|c|c|c|c|c|c|c|c|c|c|}
\hline & 年 & $30=$ & 代 & 40 & 代 & $50=$ & & & t \\
\hline & 性 & 男 & 女 & 男 & 女 & 男 & 女 & 男 & 女 \\
\hline & 症 例 数 & 15 & 20 & 30 & 52 & 32 & 38 & 77 & 110 \\
\hline & 正 常 のまま & $11(73.3)$ & $12(60.0)$ & $16(53.3)$ & $31(59.6)$ & $18(56.3)$ & $20(52.6)$ & $45(58.4)$ & $63(57.3)$ \\
\hline 肥 & 肥 満 のまま & $4(26.7)$ & $2(10.0)$ & $10(33.3)$ & $9(17.3)$ & $10(31.3)$ & $9(23.7)$ & $24(31.2)$ & $20(18.2)$ \\
\hline 満 & 肥 満 $\rightarrow$ 正 常 & 0 & $1(5.0)$ & 0 & $3(5.8)$ & 0 & $1(2.6)$ & 0 & $5(4.5)$ \\
\hline 度 & 肥 満 $\rightarrow$ や 女 & 0 & $1(5.0)$ & 0 & 0 & 0 & 0 & 0 & $1(0.9)$ \\
\hline$\infty$ & 正 常 $\rightarrow$ 肥 満 & 0 & $2(10.0)$ & $1(3.3)$ & $3(5.8)$ & $4(12.5)$ & $3(7.9)$ & $5(6.5)$ & $8(7.3)$ \\
\hline (4) & やせのまま & 0 & $1(5.0)$ & $3(10.0)$ & $3(5.8)$ & 0 & $3(7.9)$ & $3(3.9)$ & $7(6.4)$ \\
\hline 変 & 正常 $\rightarrow$ や 世 & 0 & $1(5.0)$ & 0 & 0 & 0 & 0 & 0 & $1(0.9)$ \\
\hline 化 & やせ $\rightarrow$ 正常 & 0 & 0 & 0 & $2(3.8)$ & 0 & $2(5.3)$ & 0 & $4(3.6)$ \\
\hline & やせ $\rightarrow$ 肥満 & 0 & 0 & 0 & $1(1.9)$ & 0 & 0 & 0 & $1(0.9)$ \\
\hline 血 & 正 常のまま & $14(93.3)$ & $20(100)$ & $27(90.0)$ & $45(86.5)$ & $23(71.9)$ & $26(68.4)$ & $64(83.1)$ & $91(82.7)$ \\
\hline 压 & 高血圧 $\rightarrow$ 正常 & 0 & 0 & $1(3.3)$ & $2(3.8)$ & $2(6.3)$ & $4(10.5)$ & $3(3.9)$ & $6(5.5)$ \\
\hline 変 & 正常 $\rightarrow$ 高血圧 & 0 & 0 & 0 & $3(5.8)$ & $3(9.4)$ & $5(13.2)$ & $3(3.9)$ & $8(7.3)$ \\
\hline 化 & 高血圧のまま & $1(6.7)$ & 0 & $2(6.7)$ & $2(3.8)$ & $4(12.5)$ & $3(7.9)$ & $7(9.1)$ & $5(4.5)$ \\
\hline 心 & I の まま & $1(6.7)$ & 0 & 0 & $3(5.8)$ & $1(3.1)$ & $1(2.6)$ & $2(2.6)$ & $4(3.6)$ \\
\hline 黾 & $\mathrm{I} \quad \rightarrow \quad \mathrm{O}$ & 0 & 0 & 0 & $1(1.9)$ & $1(3.1)$ & 0 & $1(1.3)$ & $1(0.9)$ \\
\hline 変 & $\mathrm{O} \quad \rightarrow \quad \mathrm{I}$ & 0 & $1(5.0)$ & $2(6.7)$ & $3(5.8)$ & $1(3.1)$ & $2(5.3)$ & $3(3.9)$ & $6(5.5)$ \\
\hline 化 & O の まま & $14(93.3)$ & $19(95.0)$ & $28(93.3)$ & $45(86.5)$ & $29(90.6)$ & $35(92.1)$ & $71(92.2)$ & $99(90.0)$ \\
\hline 貧 & 貧血 $\rightarrow$ 正常 & 0 & $2(10.0)$ & 0 & $2(3.8)$ & 0 & 0 & 0 & $4(3.6)$ \\
\hline 血 & 正常 $\rightarrow$ 貧 血 & 0 & 0 & 0 & $1(1.9)$ & 0 & $1(2.6)$ & 0 & $2(1.8)$ \\
\hline 変 & 貧血のまま & 0 & $2(10.0)$ & 0 & $2(3.8)$ & 0 & $1(2.6)$ & 0 & $5(4.5)$ \\
\hline 化 & 正常のまま & $15(100)$ & $16(80.0)$ & $30(100)$ & $47(90.4)$ & $32(100)$ & $36(94.7)$ & $77(100)$ & $99(90.0)$ \\
\hline 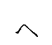 & 高へマトのまま & 0 & 0 & 0 & 0 & 0 & $1(2.6)$ & 0 & $1(0.9)$ \\
\hline$\vec{P}$ & 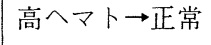 & 0 & 0 & 0 & 0 & 0 & 0 & 0 & 0 \\
\hline$r$ & 正常 $\rightarrow$ 高ヘマト & 0 & 0 & $1(6.7)$ & 0 & 0 & $1(2.6)$ & $1(1.3)$ & $1(0.9)$ \\
\hline ") & 正常 のまま & $15(100)$ & $19(95.0)$ & $29(96.7)$ & $49(94.2)$ & $32(100)$ & $35(92.1)$ & $76(98.7)$ & $103(93.6)$ \\
\hline$r$ & 低へマトのまま & 0 & 0 & 0 & 0 & 0 & 0 & 0 & 0 \\
\hline 変 & 低へマト $\rightarrow$ 正常 & 0 & $1(5.0)$ & 0 & $3(5.8)$ & 0 & $1(2.6)$ & 0 & $5(4.5)$ \\
\hline 化 & 正常 $\rightarrow$ 低ヘマト & 0 & 0 & 0 & 0 & 0 & 0 & 0 & 0 \\
\hline
\end{tabular}

（註） I：虚血性変化 $\mathrm{O}$ ：正常あるいは虚血性以外の変化 高へマト：高へマトクリット 低へマト：低へマトクリット

していたが，男女とも 4 〜 $5 \%$ ののは虚血性变化を 発症しており，反対に虚血性变化が改善したものはご く少数であった。

貧血は女性のみにみられたが，改善されたものは 36\%であったのに対し，貧血のまま経過したか，ある いは負血を発症したものが $6.3 \%$ あた。

ヘマトクリットでは大多数の男女とも正常のまま経 過していた。

耐糖能の変化についてみると大半の男女は正常型あ るいは境界型糖尿病のまま経過していたが，糖尿病型 に進展したものも少数みられた。
コレステロールでは大半は正常範囲内で経過してい たが，高あるいは低コレステロール血症のまま経過す るか，をたはそれらに進展するものが改善するものの 率より高かった。

中性脂肪は女性より男性に変動が多く, 40 才代, 50 才代の男性で高中性脂肪血症に進展する率が高いよ5 であった。

尿酸では女性は殆ど正常範囲内にとどまっている が，男性では高尿酸血症の改善がかなりみられた。

アルブミンは男女とも全員正常範囲内にとどまって いた。 
コリンエステラーゼは男女とも大半は正常範用のま ま経過していたが，10\%程度はコリンェステラーゼの 低下を来たしていた。また逆に改善は 4 \% 程度であっ た。

（4）小括 同一対象について第 1 年度と第 2 年度の 調查成績を異常頻度，測定項目平均値，個人別経年変 化の 3 方面より検討してみた。今回の調査対象は第 1 年度の調查対象と異なっており異常頻度に多少の違い がみられる。対照として表 4 の右端に昭和 52 年度およ び53年度に実施した広島県全県下にわたる検診結果 （治療中のものを含み，且つ年代は30才より50才代ま でをとった）を示したが，経時変化の調査対象では境 界型糖尿病, 高尿酸血症, コリンエステラーゼ低下者 以外の異常頻度は対照とほぼ同程度かあるいは低率で あった。

第 1 年度と第 2 年度の医学的検査を比較してみると 大多数のものは各項目ごとにとりあげた場合, 正常範 囲内で推移しているが, 肥満, 高血圧の改善は充分で なく，心電図虚血性変化，高コレステロール血症，高 中性脂肪血症, 低コリンェステラーゼ血症は増加傾向 が，また耐糖能と高尿酸血症は改善傾向がみられ，経 年変化の成績としては一部満足すべきものがないでは なかった。第 1 年度の対象に比べ今回の対象にはやや 異常頻度が高い,傾向がみられたが，血色素，へマトク
リット，コレステロール，中性脂肪，尿酸，アルブミ ン, コリンェステラーゼの現在用いている規準は健康 の基礎的指標としての血液性状值としてかなり評価し 得るものではないかと考えられる。

\section{3 . 第 3 年度研究}

昭和53，54年度にわたり広島県農村地域で検診を受 けた農業従事者より無作為に抽出した自ら健康と考光 ている30才代より60才代にわたる男性109人，女性198 人（表 7 参照）に対し，大和田式変法により栄養摂取

表 7. 対 象

\begin{tabular}{c|c|c|c|c|c}
\hline & 30 才代 & 40 才代 & 50 才代 & 60 才代 & 計 \\
\hline 男性 & 8 & 30 & 38 & 33 & 109 \\
女性 & 14 & 69 & 81 & 34 & 198
\end{tabular}

量調査を行ない，これら対象を労働時間別すなわち労 働時間 5 時間以下， $5 \sim 9$ 時間， 9 時間以上の 3 群に 分類して, 性別に異常頻度, 各項目平均値, 栄養摂取 状態を比較検討した。

（1）表 1 に示した規準に従い性別，労働時間別に分 類した異常頻度の出現率を表 8 に示した。

表 8. 性別, 労働時間別異常頻度一覧

（）は\%

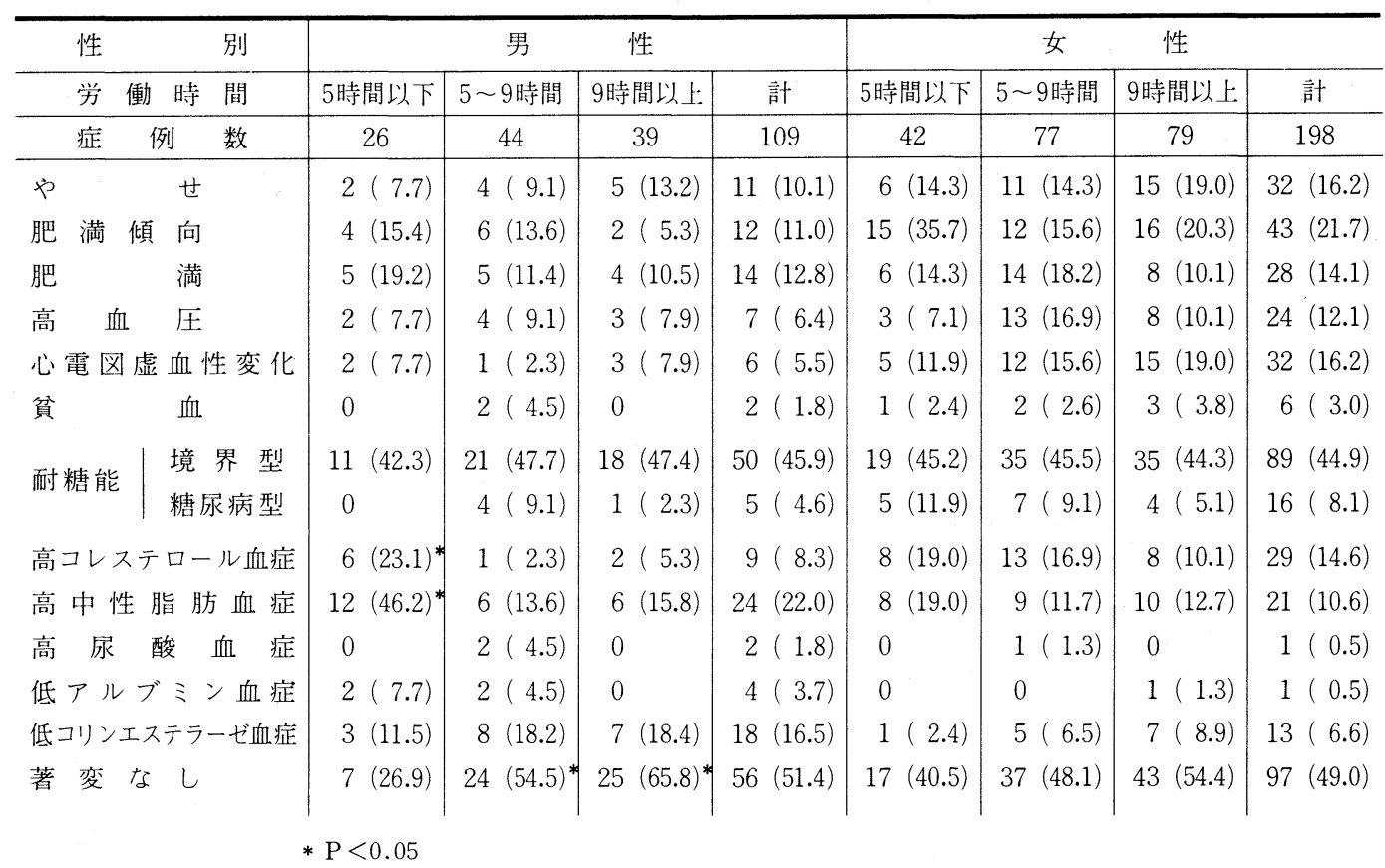


肥満は男性では労働時間の短いものほど高率であっ たが，女性では労働時間 $5 \sim 9$ 時間のものが高率で あった。

高血圧は男性では労働時間により大差はなかった が, 女性では労働時間の短い群が低率で, 労働時間 5 〜9時間群がもっとも高率であった。

心電図虚血性変化は男性では労働時間之特別の関係 はないよらであったが，女性では労働時間が長いほど 高率であった。

觼血および高尿酸血症は男女とも労働時間とあまり 関係はないよらであった。

耐糖能についてみると境界型糖尿病は男女ともかな り高率であったが, 労動時間には関係なかった。糖尿 病型は男女とも労働時間が短いほど高率の傾向がみら れた。

高コレステロール血症および高中性脂肪血症も労働 時間が短いほど高率にみられる傾向があった。

低アルブミン血症は男性では労働時間が短いほど高 率であったが，女性では労働時間と関係はないよらで あった。

血清コリンエステラーゼ低下者は男女とも労働時間 の長いものほど高率であった。

(2) 労働時間別に各項目の平均值をみると表 9 のよ らになった。

肥満度は男女とも労働時間が長いほど低い傾向が
あった。

収縮期血圧, 拡張期血圧, 血色素, 空腹時血糖, 尿 酸は男女とも労働時間と関係はみられなかった。

$50 \mathrm{~g}$ 経ロブドー糖負荷後 1 時間および 2 時間血糖值 は男性では労働時間 $5 \sim 6$ 時間群が高く, 女性では労 㗢時間との関係はみられなかった。

総コレステロール, 中性脂肪は男女とも労働時間が 短いものほど高値を示した。

アルブミンは男性では労働時間が長いほど高值を示 したが，女性では労働時間と関係ないようであった。 血清コリンェステラーゼは男女とも労働時間の短い ものほど低値を示した。

(3) 労働時間別に栄盖摂取状態をみると表10のよう になった。

総熱量並びに植物性蛋白, 総含水炭素, 複合含水炭 素の摂取は男女とも労働時間が長いほぼ多い傾向が あった。

動物性脂肪は男性では労働時間と関係ないようで あったが，女性では労働時間が長い、ど摂取量は多い 傾向がみられた。

食塩に関しては男女とも労働時間 5 時間以下の群の 摂取がもっとも多かった。

総蛋白質, 動物性蛋白質, 総脂肪, 植物性脂肪, 単 一糖質については男女とも労働時間と特別の関係はな いよらであった。

表 9. 調査項目の性別, 労働時間別平均值一覧

\begin{tabular}{|c|c|c|c|c|c|c|}
\hline 性 & \multicolumn{3}{|c|}{ 男 } & \multicolumn{3}{|c|}{ 女 性 } \\
\hline 労 働 時 間 & 5時間以下 & 5～9時間 & 9時間以上 & 5時間以下 & 5〜9時間 & 9時間以上 \\
\hline 症 例 数 & 26 & 44 & 38 & 42 & 77 & 79 \\
\hline 肥 満 度 $\quad(\%)$ & $107 \pm 14$ & $103 \pm 13$ & $101 \pm 11$ & $109 \pm 18$ & $106 \pm 15$ & $103 \pm 14$ \\
\hline 収縮 期 血圧 (mmHg) & $129 \pm 15$ & $133 \pm 14$ & $131 \pm 20$ & $134 \pm 16$ & $133 \pm 21$ & $130 \pm 19$ \\
\hline 拡張 期 血圧 $(\mathrm{mmHg})$ & $77 \pm 9$ & $79 \pm 10$ & $78 \pm 12$ & $77 \pm 8$ & $77 \pm 12$ & $77 \pm 10$ \\
\hline 血色素 量 $(\mathrm{g} / \mathrm{dl})$ & $15.2 \pm 0.95$ & $14.5 \pm 1.73$ & $14.7 \pm 1.18$ & $13.2 \pm 1.26$ & $13.0 \pm 0.82$ & $13.0 \pm 1.05$ \\
\hline 空腹時血糖 & $82 \pm 12.2$ & $86 \pm 11.0$ & $88 \pm 10.3$ & $87 \pm 10.4$ & $87 \pm 10.8$ & $88 \pm 12.5$ \\
\hline 1 時間血糖 & $152 \pm 47.0$ & $166 \pm 46.3$ & $153 \pm 43.1$ & $160 \pm 36.9$ & $159 \pm 40.4$ & $162 \pm 46.9$ \\
\hline 2 時間血糖 & $87 \pm 25.3$ & $96 \pm 36.4$ & $84 \pm 24.3$ & $107 \pm 30.5$ & $109 \pm 33.9$ & $104 \pm 28.1$ \\
\hline コレステロール $(\mathrm{mg} / \mathrm{dl})$ & $206 \pm 44.7$ & $185 \pm 32.3$ & $187 \pm 35.3$ & $215 \pm 40.0$ & $203 \pm 41.1$ & $201 \pm 36.0$ \\
\hline 中 性 脂 肪 $(\mathrm{mg} / \mathrm{dl})$ & $149 \pm 84.3$ & $108 \pm 60.4$ & $94 \pm 35.1$ & $112 \pm 54.1$ & $97 \pm 37.0$ & $95 \pm 43.2$ \\
\hline アルブミン $(\mathrm{g} / \mathrm{d} \mathrm{l})$ & $4.2 \pm 0.36$ & $4.2 \pm 0.33$ & $4.3 \pm 0.30$ & $4.4 \pm 0.31$ & $4.3 \pm 0.26$ & $4.3 \pm 0.28$ \\
\hline 酸 $(\mathrm{mg} / \mathrm{dl})$ & $4.3 \pm 0.99$ & $4.2 \pm 1.13$ & $4.4 \pm 0.78$ & $3.4 \pm 0.65$ & $3.5 \pm 0.76$ & $3.2 \pm 0.66$ \\
\hline コリンエステラーゼ $\quad(\Delta \mathrm{pH})$ & $0.85 \pm 0.25$ & $0.75 \pm 0.12$ & $0.75 \pm 0.22$ & $0.86 \pm 0.15$ & $0.82 \pm 0.14$ & $0.78 \pm 0.12$ \\
\hline
\end{tabular}


表10．性別，労動時間別，栄養摂取量一覧

\begin{tabular}{|c|c|c|c|c|c|c|c|c|}
\hline \multicolumn{2}{|r|}{ 性 } & 別 & \multicolumn{3}{|c|}{ 男 } & \multicolumn{3}{|c|}{ 女 性 } \\
\hline & 労 1 & 働 時 間 & 5 時間以下 & 5～9時間 & 9 時間以上 & 5 時間以下 & 5〜9時間 & 9 時間以上 \\
\hline & 症 & 例 数 & 26 & 44 & 38 & 42 & 77 & 79 \\
\hline \multirow[t]{2}{*}{ 総 } & 熱 & 量 (Cal) & $2321 \pm 518$ & $2402 \pm 606$ & $2669 \pm 686$ & $1861 \pm 376$ & $2066 \pm 425$ & $2106 \pm 535$ \\
\hline & & 総 量（g） & $75 \pm 17$ & $72 \pm 20$ & $80 \pm 22$ & $62 \pm 14$ & $68 \pm 15$ & $69 \pm 18$ \\
\hline \multirow{3}{*}{\multicolumn{2}{|c|}{ 蛋白 }} & 動物性（g） & $41 \pm 17$ & $35 \pm 14$ & $39 \pm 18$ & $32 \pm 12$ & $35 \pm 11$ & $34 \pm 13$ \\
\hline & & 植物性（g） & $34 \pm 8$ & $38 \pm 10$ & $40 \pm 10$ & $30 \pm 6$ & $33 \pm 8$ & $35 \pm 8$ \\
\hline & & 総 量 $(\mathrm{g})$ & $43 \pm 22$ & $40 \pm 17$ & $47 \pm 20$ & $38 \pm 14$ & $44 \pm 14$ & $43 \pm 17$ \\
\hline \multirow[t]{3}{*}{ 脂 } & 肪 & 動物性（g） & $27 \pm 17$ & $24 \pm 13$ & $30 \pm 15$ & $23 \pm 10$ & $25 \pm 10$ & $26 \pm 13$ \\
\hline & & 植物性（g） & $16 \pm 8$ & $15 \pm 7$ & $17 \pm 10$ & $15 \pm 7$ & $19 \pm 8$ & $17 \pm 7$ \\
\hline & & 総 量 $(\mathrm{g})$ & $366 \pm 93$ & $398 \pm 114$ & $429 \pm 123$ & $309 \pm 72$ & $343 \pm 83$ & $359 \pm 93$ \\
\hline \multirow{2}{*}{\multicolumn{2}{|c|}{ 含水炭素 }} & 複 合 $(\mathrm{g})$ & $298 \pm 79$ & $344 \pm 100$ & $362 \pm 104$ & $241 \pm 70$ & $280 \pm 78$ & $295 \pm 68$ \\
\hline & & 単 一 $(\mathrm{g})$ & $68 \pm 38$ & $63 \pm 38$ & $67 \pm 31$ & $68 \pm 33$ & $63 \pm 26$ & $65 \pm 45$ \\
\hline 食 & & 塩 & $21 \pm 5.3$ & $19 \pm 6.9$ & $20 \pm 7.6$ & $21 \pm 7.0$ & $18 \pm 7.0$ & $19 \pm 7.6$ \\
\hline
\end{tabular}

平均値土標準偏差

（4） 小括 農業従事者の労働時間と栄養拱取状態が 身体状況に及ぼす影響について検討したが，健康と考 えている農業従事者の中にみられる異常頻度は第 1 年 度の成績とほぼ同様であった。しかし異常率の頻度と 各項目の平均值はかなり労働時間と関連をもつものが ある事がわかった。すなわち肥満, 糖尿病, 高コレス テロール血症, 高中性脂肪血症, 低アルブミン血症は 労働時間が短いほど不良であり, 心電図虚血性変化, 低コリンェステラーゼ血症等は労働時間が長いほど成 績が悪かったが, 高血圧, 賓血, 高尿酸血症等は労働 時間と関連はないかあっても少ないよらな傾向がみら れた。またこれらの変化と栄養摄取状態との関連をみ ると栄養摂取量特に含水炭素の摂取は労動時間の長い ものほど多いよらであり，これは当然予想されたこと ではあるが，問題は労働時間の短いものと労働時間の 長いものの間の栄養摂取量の差が大きくないことであ り, 特に総蛋白, 総脂肪, 単一糖質等では殆ど差がみ られず，この事実が労働時間の短いものに肥満，糖尿 病, 高コレステロール血症, 高中性脂肪血症等が多い ことに関連をもつものと考えられた。

なお表 8 に示してあるよらに調査した範囲内で著変 をみなかったものは男女とも労働時間の長いものに多 く, 労働時間 9 時間以上のものでは過半数に達してい る点は注目すべき問題であろら。

$$
\text { 考按 }
$$

昭和52年度より昭和 54 年度にわたって, 農村におけ
る血液性状よりみた健康の基礎的指標について検討す べく，自ら健康と考えている農村住民の医学的調査を 行ない, また同様な農業従事者に 1 年間のインターバ ルをおいて健康調査を実施し, さらに農業従事者の労 働時間と健康状態並びに摂取栄養量との関連について 検討した。自ら健康と考えている人の中にも医学的検 査を行なえば多少の異常が存在することは周知のこと であり，その頻度あるいは測定項目の平均値の多寡が 問題になる。今回の研究においては表 1 に示した様な 規準を用いて判定の基礎としたが，この規準の作定に あたっては上記した様な自ら健康と考えるものを選 び, さらに肥満, 高血圧, 検尿異常者等比較的簡単に スクリーニング出来る異常を除いた約 2,000 例の検査 成績より求めたものであり，血液性状の規準としては かなり信頼のおけるものと考えている。この様な規準 を用いて調査した結果は前述した様に全県下にわたる 調査成績より一部の項目を除いて良好な結果を得てい る。血液性状について言えばュリンェステラーゼ低下 者は対照より頻度が高かったが農業従事者を対象とし ているため農薬の影響が考えられるし，また労働時間 と相関することより，過労との関係も考えられた。ま た同一対象に対し経年観察を行なった例で他の対象よ りやや異常頻度が高かったことおよび第 1 年度に高 尿酸血症が対照より高率であったことは，対象農民の 生活へベルが比較的高いものであったことが影響した とも考之られる。また耐糖能障害のらち境界型糖尿病 は対照と同程度あるいはやや高率であったが，糖尿病 
そのものに対する概念が变化しつつあり 9)10111)，日本 糖尿病学会においても糖尿病診断基準の再検討が行な われており，論及はいましばらくさけたいと思う。

健康の指標としても血液性状に関する研究は数少な 〈, 岡田 ${ }^{3)}$, 野田 ${ }^{4)}$ 等はコレステロール, 中性脂肪, 血色素, 血清アルブミン等をとりあげて論じており, 健康と言ら大きな概念に対する指標としては充分とは 言えないまでも，かなり的を射ている様に考えられ， これらに尿酸, コリンェステラーゼ等を加えて論じた 方がよい様に思われる。

このたび実施した調査成績を総合的に考える場合， 特に血液性状よりみた健康の基礎的指標と言り問題に ついては，まだまだ充分な結論が出る段階ではないと 思らが，少なくとも現行の規準よりみて多少の異常を 持つ人も日常労働に事欠く状態ではなく, 問題はこれ らの変化が将来如何に進展していくかと言う点であろ う。その点より考えると現在問題とすべきは各種疾患 の Risk factor と言われるものについて追求すべきで あり, 健康の指標としての血液性状もこの点を充分考 慮して検討すべきであろら。この点より考えると WHO が示している健康の規準にあてはまるものは少 なく11), ここらで一考の要がある様に考える。

なお，このたびの研究では測定しなかったが，健康 の指標としてはリポ蛋白や肝機能検査も加えてゆく必 要があると考えられ，また近い将来には Tumor marker と言われるものもとりあげていかねばならないで あろら。

\section{結語}

昭和 52 年より昭和 54 年まで 3 年間にわたり農村にお ける血液性状よりみた健康の基礎的指標に関する研究 を実施した。主として自ら健康と考える農業従事者に ついて調査したが，現在使用している規準を用いて調 査結果を分析すると, これら対象にもある程度の異常
がみられたが，その大部分は Risk factor の概念に入 るものであり, これらの追跡調査が必要であると考え ると同時に, 健康の指標としての血液性状を論議する ためには，少なくとも血色素，アルブミン，コレステ ロール, 中性脂肪, 尿酸, コリンェステラーゼ等は必 要であり,これらの判定規準は現行のもので充分では ないかと考えている。なお今回の研究では症例数の問 題もあり, 分析が充分行ない得なかった点も多々ある ので今後さらに調査研究をす寸める必要があろら。

\section{文献}

1) 曾田長宗：健康の指標としての傷病統計, 日農医誌, $9: 260$ -279 , 昭36.

2 ) 二塚 信他: 農村の生活構造と健康水準, 日農医誌, $22: 15$ -31 , 昭 48 .

3 ) 岡田芳子, 他：健康指標化関する研究——血液化学値の意義 について—, 日農医誌, $24: 390-391$, 昭50.

4 ) 野田喜代一, 他 : 血液生化学値に上る動脈硬化指向指数につ いて (第 2 報), 日農医誌, $25: 470-471$, 昭51.

5 ) 岡田芳子, 他 : 健康指標の設定に関する研究 (第 4 報), 肥満 度についての緒指標の検討, 日農医誌, $26: 476-477$, 昭52.

6 ) 望月満美子, 他：血液珄状を中心とした千葉県下八ウス裁培 従事者の健康調査, 日農医誌, $27: 354-355$, 昭53.

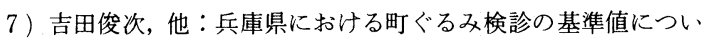
$\tau$, 日農医誌, $27: 356-357$, 昭 53.

8 ) 岡田芳子, 他：健康指標の設定に関する研究 (第 5 報), 肥満 度之循環機能検查成績について, 日農医誌, $29: 272-273$, 昭55.

9 ) National Diabetes Data Group; Classification and diagnosis of diabetes mellitus and other categories of glucose intolerance, Diabetes, 28 : 1036-1057, 1979.

10) Keen, H. et al.; Diabetes mellitus: a new look at diag. nostic criteria, Diabetologia, 16: 283-285, 1979.

11）暒沼 宏：糖尿病の糖負荷試験に上る診断- - NIH, WHO の新しい診断基準——, 医学のあゆみ, $113: 715-720$, 昭55.

12) 高科成良, 他: 広島県農村居住者と広島県出身八ワイ, ロス アンゼルス居住日系人の健康状態の比較, 日農医誌, $29: 206$ -207 , 昭 55 . 